\title{
Analyses of pectolite and stellite, and proposed union of these two species
}

\section{J.D. Whitney}

To cite this article: J.D. Whitney (1850) Analyses of pectolite and stellite, and proposed union of these two species, Philosophical Magazine Series 3, 36:246, 553-554, DOI: $10.1080 / 14786445008646545$

To link to this article: http://dx.doi.org/10.1080/14786445008646545

曲 Published online: 30 Apr 2009.

Submit your article to this journal $\pi$

Џll Article views: 2

Q View related articles $๘$ 
with the gangue; as soon as the adhering impurities have been removed, the mineral dissolves without effervescence.

The following results of an analysis will show conclusively that the nemalite is essentially hydrate of magnesia, or bruxite, from which it does not differ otherwise than by being in a fibrous state :-

$$
\begin{array}{lrr}
\text { Magnesia } \ldots \ldots \ldots \ldots \ldots \ldots & 62 \cdot 89 \\
\text { Protoxide of iron. } \ldots \ldots \ldots \ldots & 4 \cdot 65 \\
\text { Carbonic acid } \ldots \ldots \ldots \ldots \ldots & 4 \cdot 10 \\
\text { Water (by loss) } \ldots \ldots \ldots \ldots & 28 \cdot 36 \\
\hline & 100 \cdot 00
\end{array}
$$

A small portion of magnesia is replaced by protoxide of iron. The formula of brucite, $\mathrm{MgO}, \mathrm{HO}$, requires-

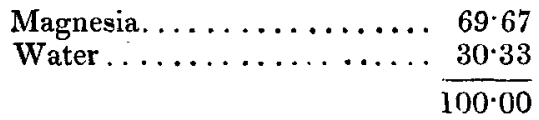

Boston Journal of Natural History, vol. vi. p. 36:

ANALYSES OF PECTOLITE AND STELLITE, AND PROPOSED UNION OF THESE TWO SPECIES. BY J. D. WHITNEY.

Pectolite occurs on Isle Royale, Lake Superior, in spheroidal masses, consisting of delicate silky fibres radiating from a centre, which exactly resemble the foreign specimens of this mineral from Monte Baldo. 'The radiated stellated mineral from Bergen Hill, New Jersey, which was analysed by Beck, and supposed by him to be identical with the stellite of Thomson, agrees also in external characters with the pectolite. Specimens from Isle Royale and from Bergen Hill fuse, like pectolite, readily, with but little intumescence,

\begin{tabular}{|c|c|c|c|c|}
\hline Silica & $\begin{array}{l}\text { I. } \\
53 \cdot 45\end{array}$ & $\begin{array}{l}\text { II. } \\
55 \cdot 66\end{array}$ & $\begin{array}{l}\text { III. } \\
54 \cdot 00\end{array}$ & $\begin{array}{c}1 \mathrm{~V} . \\
55 \cdot 00\end{array}$ \\
\hline Lime & $31 \cdot 21$ & $32 \cdot 86$ & $32 \cdot 10$ & 32.53 \\
\hline Soda & $7 \cdot 37$ & $7 \cdot 31$ & $8 \cdot 89$ & $9 \cdot 72$ \\
\hline Potash .... & trace & $\cdots$ & trace & \\
\hline Alumina .. & $4 \cdot 94$ & $1.45 \mathrm{MnO}$ & $1.90 \mathrm{Mn}$ & $1 \cdot 10$ \\
\hline \multirow[t]{2}{*}{ Water.... } & $2 \cdot 72$ & $2 \cdot 72$ & $2 \cdot 96$ & $2 \cdot 75$ \\
\hline & $99 \cdot 69$ & $100 \cdot 00$ & $99 \cdot 85 \mathrm{~J} . \mathrm{s.K}$ & $101 \cdot 10$ \\
\hline
\end{tabular}
to a colourless glass. They are easily dissolved by hydrochloric acid, the silica separating as a flocky powder.

The following are the results of the analysis of specimens of the pectolite and stellite :-

I. and II. are specimens from Isle Royale. No. I. contains a considerable portion of alumina, which is evidently not essential to the composition of the mineral, since II., resembling it entirely in external appearance, gives only $1 \frac{1}{2}$ per cent. The silica in both these Phil. Mag. S. 3. No. 246. Suppl. Vol. 36. 
analyses contained a small quantity of substance insoluble in carbonate of soda, evidently quartz, mechanically intermixed with the finely-fibrous mineral.

III. is the mineral from Bergen Hill, New Jersey, analysed by Beck. He has erroneously given 6.8 per cent. of magnesia in this mineral. Otherwise, substituting soda for magnesia, his analysis agrees pretty nearly with the one given above, which was done under my direction by Mr. J. S. Kendall. Hayes had also analysed this mineral, and corrected Beck's analysis as far as relates to the absence of magnesia and the presence of soda. He however did not find that it contained water, which is essential to the composition of pectolite.

IV. is also a fibrous mineral from Bergen Hill, which evidently agrees in composition with pectolite. It differs from the other specimen from the same locality in its fibres being straight, and not grouped together into star-like forms. This analysis was executed at my request by $\mathrm{Mr}$. G. J. Dickinson.

It is evident that these minerals all agree in chemical composition with the pectolite of Von Kobell, and also in external characters. Slight differences in the results of the analyses may easily be accounted for by the difficulty of procuring a tinely fibrous mineral in a state of known freedom from intermixture with foreign substances.

The formula given by Von Kobell for pectolite is-

$$
3\left(\mathrm{NaO}, 3 \mathrm{SiO}^{3}\right)+4\left(3 \mathrm{CaO}, 2 \mathrm{SiO}^{3}\right)+3 \mathrm{HO},
$$

which formula requires-

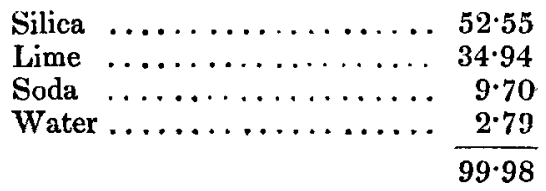

Frankenheim considers the water in the pectolite as unessential, and allies this mineral with the augite family, from which it differs widely in chemical characters. The constant presence of nearly 3 per cent. of water in all the analyses of the substance dried at $100^{\circ} \mathrm{C}$., makes it highly improbable that it should be merely accidental. In fact, the formula given above seems to be the only one which could be adopted for this mineral.

The original stellite, described by Thomson as occurring in Seotland, was probably an impure specimen of pectolite, which mineral it agrees with in external characters, as well as in chemical composition, merely substituting soda for magnesia. The mineral described by the same chemist under the name of Wollastonite, under the erroneous impression that that name had not been generally adopted for table-spar, is also evidently identical with pectolite.Boston Journal of Natural History, vol. vi. p. 40. 